\title{
VIRUSES OF DISEASES OF THE RESPIRATORY TRACT*
}

BY

\author{
C. H. STUART-HARRIS, M.D., F.R.C.P. \\ Professor of Medicine, University of Sheffield
}

Epidemiology of Acute Respiratory Disease

The usual methods for determining the prevalence of infectious disease in the community by notification of cases or by mortality records fail to provide the proper background for acute respiratory disease. This is because of the largely benign character of the illnesses and also the great difficulty in their clinical differentiation. There are of course available the notifications of pneumonia and the deaths from bronchitis, pneumonia, and influenza which certainly give valuable indications of the presence of influenza viruses in the community. Influenza epidemics are also identified by the high attackrate in adults and illnesses in the insured population which cause a sudden excess in the number of claims from National Insurance. Excluding influenza, however, one is left with the major portion of the common respiratory diseases on which there is little exact information beyond their seasonal character.

Every year, from October to March, there is a seasonal rise in all sickness insurance claims, particularly in those from acute respiratory illnesses. Epidemics such as influenza are associated with the largest increases. Abrupt increase in illnesses occurs at other times, however, and those in patients needing admission to hospital are well shown by statistics from the London Emergency Bed Service and kindly made available to me by Dr. Godber, of the Ministry of Health (see Fig.). These admissions undergo successive increases and decreases between October and April, and sharp increases occur particularly between December and February. Fogs and influenza epidemics are identifiable causes of some increases, but others are of unknown origin. Though the patients concerned are largely those with chronic disease of the chest and heart, the illnesses for which they are admitted are acute episodes of bronchitis or pneumonia with or without heart failure. Sometimes also infants and children are involved in a sudden flurry of admissions from bronchiolitis (Nicol, 1957). Holland, Spicer, and Wilson (1961) recently analysed hospital admissions from the E.B.S. during 1958 in such a way as to eliminate purely seasonal changes. A positive correlation was found between increases in atmospheric pollution or falls of temperature and increases in admissions in those aged 15 years or more. In a further study of three large recruiting stations of the R.A.F. where pollution was not a problem there was a similar correlation between increase in acute respiratory disease and cold weather.

Hope-Simpson (1958) has also demonstrated a most striking correlation between increase in the frequency

*The second of two Croonian Lectures delivered before the Royal College of Physicians of London on March 13 and 15, 1962. The first lecture appeared in the issue of June 30, 1962. of colds in a group of families in a country practice and falls in temperature recorded in the soil. Such correlations may of course be indicative of the provocative effect of environmental agencies on the host-virus relationship rather than a direct effect upon the hosts themselves. But it is also necessary to consider the effect of different humidities on the survival of viruses. Hemmes, Winkler, and Kool (1960) have found that poliovirus survives exposure to moist better than to dry air. Common-cold viruses (Tyrrell, 1961) also prefer a high relative humidity whereas influenza virus survives better in dry air. The weather may therefore provide

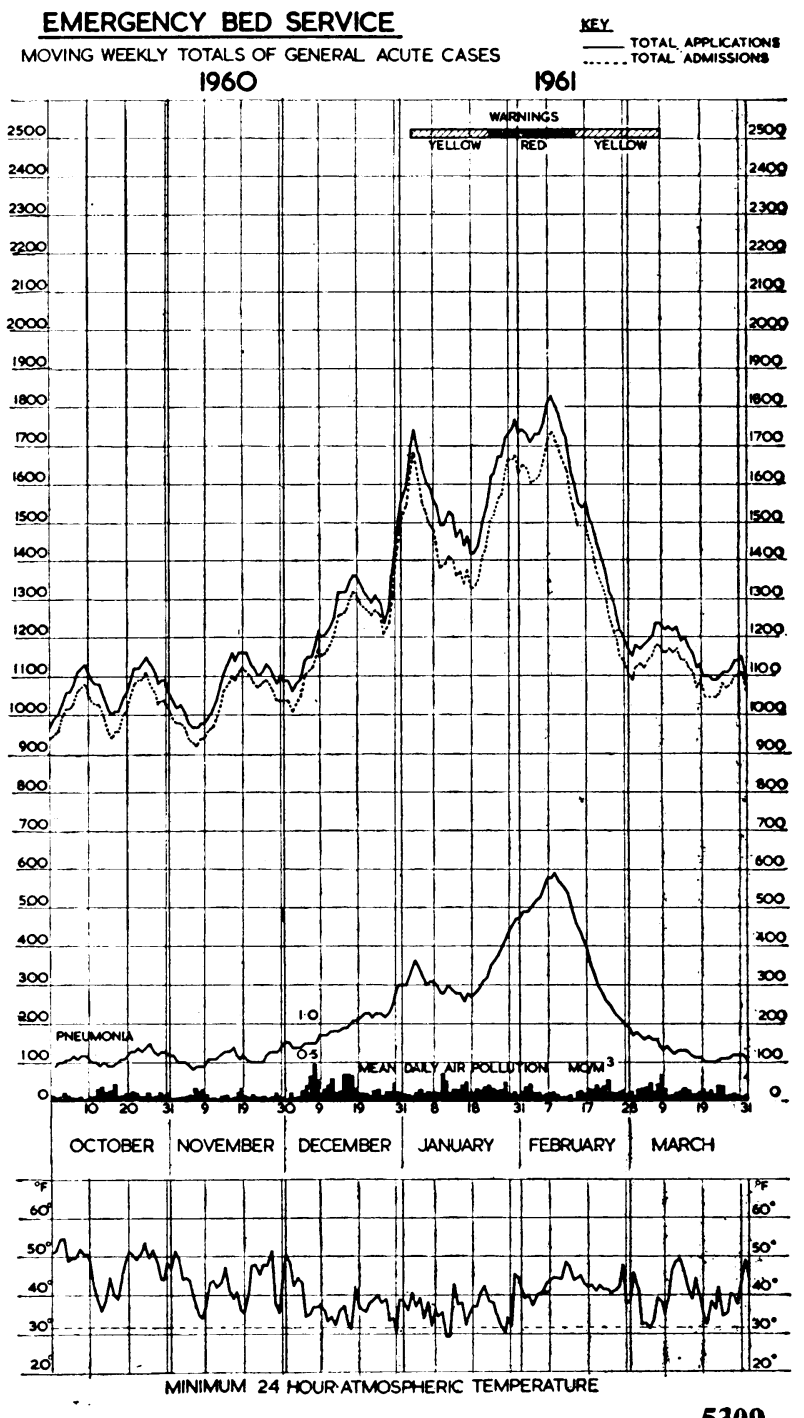


the setting required for epidsmic spread of a virus as well as the impairment of host resistance already mentioned. Yet epidemics of Asian influenza occurred in 1957 under most varied climatic conditions, and poliomyelitis has occurred from the Arctic to the tropics, so that environmental limitations can certainly be overcome by some viruses.

The succession of waves and troughs seen in the hospital admissions is reminiscent of a similar variation of prevalence in acute respiratory disease in the Services as seen in England during the second world war (StuartHarris, 1953). Similar experiences were recorded in American Servicemen by the U.S. Commission on Acute Respiratory Diseases (1946). In such residential communities, however, the incidence of disease is influenced by changes in the population due to recruitment, and it is possible. that a single infectious agent causes recurrent epidemics because of the arrival of new susceptibles in the herd.

Family illnesses have also been much studied in recent years, and these have stressed such factors as the size of the family and the effect of age on attack-rates. A group of 60 families studied in Cleveland by Badger, Dingle, Feller, Hodges, Jordan, and Rammelkamp (1953) experienced an average of 6.2 common respiratory illnesses per person per year. Children under 3 years of age had a higher attack-rate than those over 3, and children as a group had twice as many illnesses as adults. Families of four or more persons had a higher attackrate than those of three persons. The overwhelming toll of illness from acute respiratory disease revealed by these family disorders was also found in Newcastle during the Thousand Families Study (Spence et al., 1954). Yet the family doctor rarely glimpses the full impact of these ailments because the minor illnesses, which are most numerous, may not be reported unless a special study is made.

The winter epidemic season of acute respiratory disease thus appears to consist of a series of waves or outbreaks of infection with intervening periods of relative quiescence. Such a pattern may be due to separate epidemics due to different viruses. It is obvious, however, that considerable obscurity surrounds the phenomenon, and there is a great need to obtain better evidence concerning the various infectious agents and their modus operandi. They may, in fact, not be entirely independent of each other, for one agent may interfere with the transmission of another or, alternatively, one may prepare the ground for another.

\section{The Host-virus Interactions of the Respiratory Tract}

The range of clinical illnesses of the respiratory tract produced by particular viruses is a striking example of the spectrum of host-virus interactions. There are serious, even fatal, illnesses due to influenza, the adenoviruses, and the myxoviruses of the para-influenza group Yet the majority of the illnesses caused by these agents are mild and there is good evidence that many infections are subclinical. 'In questioning the reason for the variation observed in individual patients it is essential to recognize that both host and virus factors are concerned in connexion both with susceptibility or resistance and with mortaly.

Age is a most important host factor in relation to both incidence and severity of infection, but the effect is complex. The modification of infection by immunological changes brought about by previous infection is accompanied probably by a different tissue response at different ages. It is thus impossible to state the precise reason for the fact that the response of young babies or even toddlers to infection with influenza virus is different from that in older children and in adults. It is a striking fact that the very young are far less ill during influenza than older children or young adults, and may appear merely to have a runny nose. The school-age child shows a brisk febrile response but may have no headache or aching pains in the limbs. The middle-aged adult is often only mildly febrile, yet complains of severe headache and myalgia and is often depressed. Burnet (1943) suggested that the symptoms of influenza may be partly allergic in origin and dependent upon sensitization of the tissues by antibody derived from previous infection. Yet it is possible also that the products of influenza-virus multiplication are less well tolerated by old than by young tissues.

Previous disease of the respiratory tract or of the heart certainly affects the character and the severity of new acute illnesses. Thus mortality from Asian influenza in 1957-8 was increased by previous chest or heart disease. Any infection in the patient with chronic bronchitis or bronchiectasis causes increased sputum or even pneumonitis, while an upper respiratory infection in the asthmatic leads to acute attacks of asthma. Then there is a constitutional factor seen in the way in which some children become wheezy whenever they suffer from an upper respiratory infection, and others suffer from recurrent otitis media during common colds. This effect may of course have a simple anatomical explanation.

Genetically determined resistance to respiratory virus infection is most difficult to evaluate and has not been proved in man. Differences in susceptibility of various strains of mice to experimental influenzal infection of the lung have been known for some time. A more absolute form of resistance to neurotropic strains of influenza virus given intracerebrally has been found in a certain breed of mice by Lindenmann recently (1962). This is of great theoretical interest but may have no significance for man.

\section{Immunological Factors}

The role of immunological factors in determining resistance is equally difficult to assess. All the various respiratory viruses studied so far produce an essentially surface infection with temporary multiplication of the virus in the mucosa and later disappearance of the virus from the secretions. Only one group of viruses-the adenoviruses-lingers in the respiratory mucosa and can be found as latent agents in tissues removed surgically. Even among the adenoviruses latency appears to be a characteristic of certain serotypes, as will be shown later. Neutralizing antibodies appear in the serum during convalescence or, if present initially, they increase in amount and later begin to diminish. Specific antiviral substances are found in the nasal secretion also. The titre of such antibodies is high during convalescence, at least in the case of influenza (Francis and Brightman, 1941). It is clear that the level of neutralizing antibodies to influenza virus in the blood is related to the susceptibility or resistance to infection, but there is no critical level above which infection is impossible. In the case of the para-influenza myxoviruses reinfection occurs even though serum antibodies have developed as a result of a first infection (Chanock and Johnson, 1961). There is suggestive information that resistance to 
infection with some of the cold viruses may, however, be related to serum antibodies (Bynoe et al., 1961).

The temporary character of the immunity to the respiratory viruses seems likely to be due to the superficial character of the infection and absence of deeper invasion of the body via the blood-stream. Viraemia has not been shown to occur normally in influenza, though virus has been found in organs remote from the respiratory tract at necropsy in fatal influenzal pneumonia due to the Asian influenza virus (Kaji, Oseasohn, Jordan, and Dingle, 1959). Virus was thus recovered from the spleen, kidney, and heart, and it has also been recovered from the brain in fatal influenzal encephalitis (Flewett and Hoult, 1958). The fact is that for successful influenzal infection to occur in the ferret-an animal in which the disease is reasonably analogous to that in man-virus must be inoculated intranasally and does not infect even when large amounts of virus are given parenterally. The same holds for influenza in the mouse except that suckling mice can develop a generalized infection after parenteral injection of virus (Tyrrell and Cameron, 1957). Viraemia may, however, occur during adenovirus infection, though it has not yet been reported. Not only do adenovirus infections involve both respiratory and gastro-intestinal systems but Hilleman, Hodges, Warfield, and Anderson (1957) showed that intramuscular injection of living adenovirus produces a disease very similar to that following intranasal infection. It is possible that immunity to adenovirus infection may also be more long-lasting than in influenza, but because of the multiple serotypes there may be several attacks during any one person's lifetime.

\section{Other Mechanisms Determining Resistance}

Other mechanisms also exist which determine susceptibility or resistance. Isaacs and Hitchcock (1960) found that interferon is produced in the lung in mice infected with influenza virus and suggested that its presence even before antibodies were formed was a major factor in causing the virus to decline in amount in the lungs at an early stage of disease. Its absence from the lungs in fatal influenzal pneumonia in man (Baron and Isaacs, 1962) agrees with this suggestion. Interferon is probably secreted into the nasal lumen during respiratory infections, and it may be a potent factor in checking multiplication of virus in a surface infection. Nevertheless interferon action is inhibited by oxygen (Sawicki, Baron, and Isaacs, 1961), and mav therefore be less effective in surface infections. Finally, there is some variation in interferon secretion with age, for in mice the production of interferon improves with maturity (Sawicki, 1962).

The febrile reaction to many respiratory viruses may also be a purposive host response as suggested by Lwoff and Lwoff (1959). Tyrrell and Parsons (1960) were able to demonstrate multiplication of viruses from colds in tissue cultures cultivated at $33^{\circ} \mathrm{C}$. but not in similar cultures incubated at $37^{\circ} \mathrm{C}$. Tyrrell (1961) suggests that a rise in temperature of the nasal fossa above $33^{\circ} \mathrm{C}$. due to blockage could limit further virus multiplication during the course of a cold. The cause of the rise in body temperature accompanying fever is not yet understood. Influenza virus (Atkins and Huang, 1958) and also other viruses induce pyrexia when injected intravenously into non-susceptible animals. This pyrogenic effect could be due to cellular products, but the brisk reaction seen sometimes in man after the subcutaneous inoculation of concentrated inactivated virus used in influenza vaccines suggests that the virus protein is itself responsible.

Finally, the variation in clinical patterns of respiratory virus infections may be due to the complicating action of bacteria. The upper respiratory tract is colonized by bacteria, many of which are potentially pathogenic for the lung or the accessory sinuses. Influenza is the classic example of a disease modified by bacteria which may attack synchronously with the virus infection or may follow it. The precise way in which the virus modifies the resistance of the respiratory tract to bacteria is not known, though viral destruction of surface epithelium seems a likely factor. In atypical pneumonia, on the other hand, where much of the pathological effects stem from interstitial cellular infiltration without surface destruction, secondary bacterial infection of the lung is almost never seen. It is still too early to assess the bacterial contribution to diseases caused by the adenovirus or the para-influenza myxoviruses. But colds are well-known causes of sinusitis, bronchitis, or pneumonia due to bacteria, and it is possible that they too are accompanied by epithelial destruction.

Bacteria are not the full explanation for the variation in mortality in different outbreaks due to the same virus species. Excessive mortality in influenza pandemics such as that in 1918-19 is usually believed to be produced by an altered virulence of the virus largely because of the intense attack upon young adults. Equally, the mildness of the Asian influenza epidemics in 1957 is believed to reflect the relatively low virulence of the Asian strains. Burnet (1960), indeed, suggests that in 1957 the world just missed a repetition of 1918 influenza, because during the early weeks of the outbreak in the U.S.A., and also in Britain, a significant number of deaths occurred in young adults. The natural variation of virulence of the respiratory viruses is a complex and obscure subject, and those who are interested in it should refer to the discussion of the Ciba Foundation Study Group (1960).

\section{Syndromes of Acute Respiratory Diseases}

The clinician is faced by a major task in classifying the acute respiratory diseases in a way that can be related to the causative agents. Anatomical descriptions ceased to provide an adequate basis for classification once it was known that a single virus such as, for instance, influenza virus could affect the entire respiratory tract from nose to alveoli. It has also become abundantly apparent that many different viruses can attack the same anatomical area and produce essentially similar clinical illnesses. For the present, therefore, it seems sensible to advocate classification by means of broad descriptive subdivisions listing the particular features of each subdivision, as was attempted in 1953 (Stuart-Harris, 1953). The subdivisions include the syndromes of influenza, the common cold, and atypical pneumonia, which are relatively well defined. Then there are conditions such as croup, bronchiolitis, and acute pneumonitis in infants, and an indeterminate group of acute febrile states in children and adults resembling influenza yet with prominent involvement of the pharynx, the larynx, or the tracheo-bronchial tract. All these are for the present grouped under the title of unclassified acute respiratory disease ("febrile catarrh"), though it should be realized that there are no common relationships between the various named states beyond the fact that all involve the respiratory tract. Table I 
lists this group of conditions and the causative viruses recognized so far, and is an indication of the extraordinary complexity of the problem. The various groups of viruses mentioned and those recovered also from persons with colds will now be considered. Space forbids mention of influenza and atypical pneumonia.

TABLE I.-Acute Respiratory Syndromes and Viruses

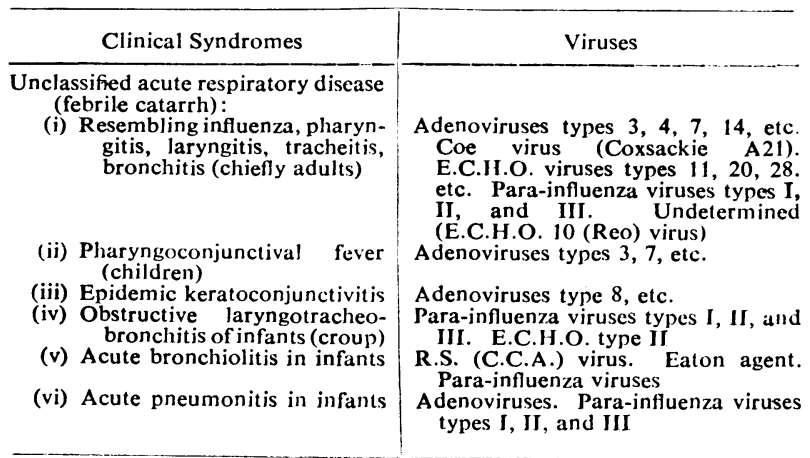

The full clinical status of para-influenza viruses types I, JI, and III, respiratory syncytial (C.C.A.), Coe, and cerrain E.C.H.O. viruses (Reo) is not yet determined.

Viruses Causing Acute Respiratory Disease : 1. The Adenoviruses

Characters of the Adenovirus

The adenovirus is a compact flat-sided particle (Valentine and Hopper, 1957) in the form of an icosahedron (Horne, Brenner, Waterson, and Wildy, 1959). It consists largely of deoxyribonucleic acid and protein, the D.N.A. being apparently situated in a central core, and the protein forming the exterior is built up from about 250 sub-units. Tissue-culture cells infected by adenoviruses develop rows of particles within the nucleus which are arranged in crystalline or irregular masses (Kjellén, Lagermalm, Svedmyr, and Thorsson, 1955 ; Morgan, Howe, Rose, and Moore, 1956). The average size of the particle is 65 to 90 millimicrons and the virus is ether-resistant.

In man, adenoviruses have been found in the throat, in adenoids and tonsils, in faeces, and in lymph-nodes of the mesenteric group. Analogous viruses have been recovered from monkeys, cattle, dogs, cats, and mice, chiefly from the gastro-intestinal tract. These animal viruses share a common complement-fixing antigen with human adenoviruses, and this so-called "soluble" antigen can be separated from the virus particles (Hilleman, Tousimis, and Werner, 1955). The particles also possess specific antigens demonstrable in neutralization tests or by means of haemagglutination (Rosen, 1958) that are type-specific. The total number of serotypes of human adenoviruses now known is 28 (Rosen, Baron, and Bell, 1961). Some types have been found much more commonly than others, and it even seems likely that there is an association between certain serotypes and particular clinical illnesses. The animal adenoviruses have their own serotypes, though monkeys or chimpanzees may harbour viruses of the same types as man.

Adenoviruses can be adapted to grow in monkeykidney-tissue cultures, though they grow more readily in serial cell lines such as the HeLa cell. Cytopathic changes do not necessarily destroy the infected cells. The viruses can be inactivated by formalin, and killed vaccines made from tissue cultures have been used in the U.S.A. to prevent respiratory illnesses. They have been shown to produce antibodies and to exert a protective effect which is partly type-specific (Hilleman, Stallones, Gauld, Warfield, and Anderson, 1957). Diagnosis in man is best effected by cultivation of throat swabs or faecal suspensions in cultures from serial cell lines. An antibody rise demonstrated by the complement-fixation test using paired sera collected in the acute stage and in convalescence is probably the most convenient method of proving an association in time between an infection by adenoviruses and a particular illness. The analogy with the diagnosis of influenza is reasonably close.

\section{Clinical Characters of Adenovirus Infection}

The first strains of the adenovirus group were recovered when Rowe, Huebner, Gilmore, Parrot, and Ward (1953) cultivated fragments of adenoids as tissue cultures, observed cytopathic changes, and successfully transmitted the degenerating effect to cultures of human carcinoma (HeLa) cells. This method of unmasking viruses which could not be recovered by the usual technique of grinding up tissues and inoculating cultures showed that a very high proportion (90\%) of surgically removed adenoids and tonsils contain latent adenoviruses. Ninety per cent. of these strains recovered from tonsils and adenoids by Huebner, Bell, and Rowe (1957) belonged to the particular serotypes 1, 2, and 5 ; but, in Britain, Pereira and Kelly (1957) also recovered a type 7 virus. This was found in adenoids removed from a baby in a town which had some months previously experienced an outbreak of type 7 infection. Apart from this there are no clues concerning the time when these latent viruses enter the body, or even whether or not they have originally caused clinical illness and thus represent the surviving particles living on symbiotically with their host.

Almost simultaneously with the work on adenoids at Bethesda, Hilleman and Werner (1954) found adenoviruses on throat swabs from Servicemen suffering from acute respiratory disease and produced clear-cut evidence that these agents were responsible for clinical illness. The work which followed produced an interesting link with the original description in Britain of outbreaks of acute respiratory disease in Servicemen and children in 1936, then grouped together under the term " febrile catarrh." This acute respiratory syndrome was separated from influenza because of the failure to find evidence of influenza virus infection (Stuart-Harris, Andrewes, and Smith, 1938 ; Stuart-Harris, 1953). A comparison of the symptomatology of these early cases with those obtained by the Commission on Acute Respiratory Disease in the U.S.A. in 1947 and of Servicemen with adenovirus infection in 1956 described by Dascomb and Hilleman shows a remarkably close parallel. Since then outbreaks of acute respiratory infection due particularly to adenovirus types 4 and 7 and also occasionally of types 3 and 14 have been found in Servicemen in the U.S.A., in Britain, in the Netherlands, and in France. The attack-rate is particularly high in recruits, and occurs even though there is no obvious community outbreak. The clinical picture is relatively constant and there is a pharyngolaryngotracheitis. Outbreaks of acute pharyngitis have occurred in children in the U.S.A., Britain, France, Finland, Sweden, and Japan. Types 3 and 7 have been chiefly recovered from these outbreaks, which have affected residential schools, institutions, camps, and even children in hospital. School outbreaks in Britain 
occurred in 1955 (Tyrrell, Balducci, and Zaiman, 1956 ; Kendall, Riddle, Tuck, Rodan, Andrewes, and McDonatd, 1957), but seem to have been encountered less frequently since that year. The clinical picture described originally as pharyngo-conjunctival fever (Bell, Rowe, Engler, Parrott, and Huebner, 1955) included sharp pyrexia, an acute pharyngitis with or without a mueopurulent exudate, and some cervical glandular enlargement. Minor abdominal symptoms such as pain, vomiting, and diarrhoea also occurred. A follicular or angular conjunctivitis was found in many outbreaks but was not invariable. Possibly outbreaks originating in swimming-baths may have overemphasized the frequency of conjunctivitis.

Sporadic cases of acute pharyngitis have also been reported in children living at home, and other types, including 1, 2, 5, and 6, have been found. A more severe illness in infants in France reported by Chany, Lépine, Lelong, Le-Tan-Vinh, Satgé, and Virat (1958) was associated with type 7 virus and caused pneumonic lesions and deaths in eight children. Meningeal lesions were also found in one case and virus was recovered from the brain and cerebrospinal fluid. Such pneumonic lesions have been reported also in adults with a clinical picture resembling atypical pneumonia both in the U.S.A. (Dascomb and Hilleman, 1956) and by Löftler. Spengler, Riva, Stucki, and Mangold (1956) in Switzerland.

A non-respiratory illness associated with adenoviruses which must be mentioned is an epidemic keratoconjunctivities due chiefly to type 8 virus. It has caused outbreaks in shipyard workers in the U.S.A. (Jawetz, Hanna, Kimura, and Thygeson, 1956) and in Scotland (Bennett, Law, Hamilton, and Macdonald, 1957). Possibly grit flying in the air aids the development of eye lesions.

Finally, the occurrence of gastro-intestinal symptoms accompanying respiratory illnesses emphasizes the fact that adenoviruses are found in the faeces and probably multiply in the intestinal mucosa. Gardner, McGregor, and Dick (1960) and Duncan and Hutchison (1961) have both drawn attention to the need to search for adenoviruses in outbreaks where vomiting and diarrhoea have occurred side-by-side with respiratory symptoms. An association between adenoviruses and mesenteric adenitis was reported by Swedish workers (Kjellén, Sterner, and Svedmyr, 1957), but appears to be inconstant. The suggestion that an adenovirus infection may provoke the occurrence of intussusception (Ross and Potter, 1961) must be accepted with caution because of the known symptomless excretion of adenoviruses in the faeces over long periods of time (Gardner, McGregor, and Dick, 1960).

A similar symptomless presence of adenoviruses in the throat was found during a longitudinal study made by Sutton (1962) in an orphanage for children under 5 in Sheffield. There is good evidence, therefore, that types 1 and 2 and probably 5 and 6 also are ubiquitous agents in children producing little disease and persisting in the pharynx as latent viruses. It is strange that such latent infection has not been found to be reactivated into clinical disease as occurs with herpes virus. Presumably the high level of neutralizing antibodies inhibits virus spread to the other tissues. The other group of adenoviruses including types 3,4 , and 7 are pathogenic, cause outbreaks in children and adults intermittently, and probably immunize against homotypic reinfection. The higher types of adenoviruses remain largely unknown from the standpoint of clinical illness.

Very little is known also concerning the long-term variation of adenovirus infection in the community. Viruses spread probably by the respiratory route, but faecal-oral transmission is certainly possible and may occur particularly in summer outbreaks. In view of the rather small proportion of community respiratory disease due to the adenoviruses the use of vaccine to prevent infection does not seem likely to be rewarding. However, a reduction of illness in Servicemen may be worth while under certain circumstances.

\section{The Para-influenza Myxoviruses Characters of the Viruses}

The recovery by Chanock (1956) in the U.S.A. and by Beale, McLeod, Stackiw, and Rhodes (1958) in Canada of a haemagglutinating virus from throat swabs from children with obstructive laryngotracheobronchitis (croup) opened the door to fresh discoveries. After a brief pause two further myxoviruses were found which were closely similar to the croup virus in general properties, but which were different serologically from the latter and from each other (Chanock et at., 1958). A fourth serotype has since been found (Johnson, Chanock, Cook, and Huebner, 1960), and these four agents are now classified as the para-influenza viruses types I to IV (Andrewes, Bang, Chanock, and Zhdanov, 1959). These "little cousins" of the influenza viruses resemble the latter only in that their particles are of medium size (90 to 200 millimicrons), that they form haemagglutinins for fowl and guinea-pig red cells, and that they are destroyed by ethyl ether (ether-sensitive). Like the influenza-A viruses, the para-influenza viruses are not confined in their host range to man, because analogous viruses with similar antigens are found in other animal species. Thus a mouse virus known as the Sendai agent, found first in Japan by Kuroya, Ishida, and Shiratori (1953), is serologically related to type I para-influenza virus. Bovine strains of type III para-influenza virus have also been found in cattle with "shipping-fever" (Abinanti, Byrne, Watson, Poelma, Lucas, and Huebner, 1960). Unfortunately no antigen common to the four types of human para-influenza viruses appears to exist, though there are undoubted group relationships between the various virus types and with mumps virus (Cook, Andrews, Fox, Turner, James, and Chanock, 1959). Some strains can be cultivated in fertile hens' eggs, but most require monkey or human tissue cultures.

\section{Role of the Para-influenza Viruses in Disease}

These viruses have been studied largely by cultivation of human specimens in monkey-kidney-tissue cultures and by serological methods. They have been found in the throat but not in the faeces. They cause a transient infection of the respiratory mucosa which gives rise to an antibody response as determined by complementfixation or haemagglutination-inhibition tests (Chanock, Wong, Huebner, and Bell, 1960). Reinfection can occur even in those possessing neutralizing antibodies during outbreaks of disease among groups of children in an institution (Chanock, Bell, and Parrott, 1961). Nevertheless, studies in Washington among hospital patients (Kapikian, Chanock, Bell, Reichelderfer, and Huebner, 1960) have strongly suggested an association between infection by these viruses and clinical illness. The main impact of infection appears to be in children, and parti- 
cularly in infants (Table II). Minor respiratory illnesses resembling colds, acute laryngotracheobronchitis and even pneumonia in infants or children under 5 have yielded chiefly para-influenza virus type I or type III. Type II virus was originally recovered from children with croup, but more-detailed studies in Washington (Vargosko et al., 1959) suggest that type I virus is the

TABLE II.-Para-influenza Myxoviruses. Ether-sensitive, Haemagglutinating; Culture Monkey Kidney; Size 80-120 mu. 4 Sero-types:Cross-relationship with Human Sera

\begin{tabular}{|c|c|c|c|}
\hline $\begin{array}{l}\text { Virus } \\
\text { Serotypes }\end{array}$ & Strains & $\underset{\text { Infections }}{\text { Natural }}$ & Volunteers \\
\hline Type I & $\begin{array}{l}\text { Sendai } \\
\text { Haemadsorption } \\
\text { II }\end{array}$ & $\begin{array}{l}\text { Acute lower res- } \\
\text { piratory infec- } \\
\text { tions and croup } \\
\text { (infants) } \\
\text { Minor A.R.D. } \\
\text { (adults) }\end{array}$ & $\begin{array}{l}\text { " Cold-like" ill- } \\
\text { illnesses } \\
\text { Minor pyrexia }\end{array}$ \\
\hline Type II & $\begin{array}{l}\text { Croup-associated } \\
\text { Acute laryngo- } \\
\text { tracheobronchi- } \\
\text { tis }\end{array}$ & Croup & 一 \\
\hline Type III \{ & Haemadsorption I & $\begin{array}{l}\text { Acute lower res- } \\
\text { piratory infec- } \\
\text { tions with coryza } \\
\text { (infants) } \\
\text { Minor A.R.D. } \\
\text { (adults) }\end{array}$ & $\begin{array}{l}\text { " Cold-like" } \\
\text { illnesses } \\
\text { Minor pyrexia }\end{array}$ \\
\hline
\end{tabular}

Type IV recovered only in U.S.A. infants and adults

main culprit in this syndrome. Pereira and Fisher (1960) recovered a type II virus from children with croup in South-east England in 1958, but relatively few isolations have been made elsewhere. It is extremely difficult to know whether the word croup is used in the U.S.A. to describe minor illnesses or whether it is restricted to the serious condition with croupy cough, hoarseness of the voice, stridor, and dyspnoea as is more customary in Canada (Peach and Zaiman, 1959).

In adults, illnesses due to infection with para-influenza viruses have been reported infrequently (Bloom, Johnson, Jacobsen, and Chanock, 1961). Evans (1960) found that $8.5 \%$ of acute respiratory illnesses among university students in Wisconsin were due to para-influenza type III virus and a further $1.5 \%$ were due to type I. Dick, Mogabgab, and Holmes (1961) found 2.6\% of upper respiratory disease in adults in the Southern U.S.A. due to para-influenza $I$ in 1958 and 1959. The clinical picture was not distinctive in either series. Inoculation of volunteers at Salisbury (Tyrrell, Bynoe, Peterson, Sutton, and Pereira, 1959) showed that either type I or type III viruses produced cold-like illnesses in adults. Occasionally an illness resembling influenza occurred, but pyrexia was unusual either in these British adults or in volunteers inoculated in the U.S.A. (Reichelderfer, Chanock, Craighead, Huebner, Turner, James, and Ward, 1958 ; Kapikian, Chanock, Reichelderfer, Ward, Huebner, and Bell, 1961). Infection was produced in these volunteers even though serum antibodies were present before inoculation. Nevertheless it seems possible that antibodies may modify the severity of clinical attack and perhaps determine the difference between the clinical pictures of infection in children and in adults. Serological studies have also shown a difference in the rate of acquisition of antibodies with age. Antibodies to types I and III viruses appear rapidly and are present in a high proportion of infants by the age of 2. Type II antibody is found in only about $30 \%$ of sera from children under 8 and thereafter increases in frequency (Clarke and Saynor, 1959), thus suggesting a different epidemiological behaviour from types I and III viruses. In the meantime evidence is mounting that tests with Sendai virus made by a number of workers reveal antibodies against the common antigen with parainfluenza virus type $I$ rather than specific antibodies directed against this strain.

\section{Respiratory Syncytial Virus (Table III)}

The next virus to be considered is remarkable in several ways. The first strain to be recovered was obtained from a chimpanzee with a cold (Morris, Blount, and Savage, 1956). Yet other isolations from children of a similar virus suggest that it is a single species and not one with multiple serotypes. The virus causes a characteristic morphological alteration in tissue culture and is associated with a rather definite clinical pattern of illness in children. It is now known as the respiratory syncytial (R.S.) virus because tissue culture in serial cell lines such as HeLa or Hep II develop large giant cells or syncytia. It is of medium size, being between 90 and 130 millimicrons in diameter and is ether-sensitive. It does not produce haemagglutination but has a

\begin{tabular}{|c|c|c|c|}
\hline Virus & Strains & Natural Infections & Volunteers \\
\hline $\begin{array}{l}\text { Respiratory } \\
\text { syncytial } \\
\text { (1 serotype) } \\
\text { Size } 90130 \mathrm{~m} \mu\end{array}$ & $\begin{array}{l}\text { Chimpanzee } \\
\text { coryza } \\
\text { agent } \\
\text { R.S. virus }\end{array}$ & $\begin{array}{l}\text { Acute bronchiolit is } \\
\text { (infants and } \\
\text { children) } \\
\text { Minor A.R.D. } \\
\text { (adults) }\end{array}$ & $\begin{array}{c}\text { "Cold-like " } \\
\text { illnesses }\end{array}$ \\
\hline $\begin{array}{l}\text { Reo viruses } 3 \\
\text { serotypes) } \\
\text { Size } 7080 \mathrm{~m} \mu\end{array}$ & E.C.H.O. 10 & $\begin{array}{l}\text { Coryza and diar- } \\
\text { rhoea (infants) }\end{array}$ & 一 \\
\hline E.C.H.O. type & & $\underset{\text { (children) }}{\text { Minor A.R.D. }}$ & $\begin{array}{l}\text { Minor illness; ali- } \\
\text { mentary symp } \\
\text { toms }\end{array}$ \\
\hline E.C.H.O. type & 一 & $\begin{array}{l}\text { Coryza and diar- } \\
\text { rhoea (infants) }\end{array}$ & $\begin{array}{l}\text { "Influenza-like" } \\
\text { fever and sore } \\
\text { throat }\end{array}$ \\
\hline $\begin{array}{l}\text { Coxsackie A21 } \\
\text { Size } 20 \mathrm{~m} \mu\end{array}$ & $\mathrm{Coo}$ & $\begin{array}{l}\text { Acute respiratory } \\
\text { illness resemb- } \\
\text { ling influenza } \\
\text { (recruits) }\end{array}$ & $\begin{array}{l}\text { Febrile acute resp. } \\
\text { illness }\end{array}$ \\
\hline
\end{tabular}

complement-fixing antigen which may be distinct from the infective particle (Chanock, Roizman, and Myers, 1957). Neutralizing and complement-fixing antibodies appear in the serum during convalescence from infection. The virus has not been reported to be present in the faeces, but is recovered from throat swabs, and it is remarkably labile on storage, being readily inactivated by freezing and thawing.

Human infection with R.S. virus was first recorded by Chanock and Finberg (1957), and only two strains of virus have yet been recovered in this country-both at Bristol from infants with acute bronchiolitis (Peacock and Clarke, 1961). Three groups of investigators in the U.S.A. have recovered many strains of R.S. virus, chiefly from children under 10 years of age with various forms of disease of the lower respiratory tract, including bronchitis, bronchiolitis, and bronchopneumonia. Upper respiratory signs such as coryza or a croupy cough were also often present (Reilly, Stokes, McClelland, Cornfeld, Hamparian, Ketler, and Hilleman, 1961). Similar clinical findings were reported from Washington by Chanock, Kim, Vargosko, Deleva, Johnson, Cumming, and Parrott (1961) during an outbreak of lowerrespiratory-tract illness in infants and children. In Chicago, Beem, Wright, Hamre, Egerer, and Oehme (1960) recovered R.S. virus from children with bronchiolitis and bronchopneumonia and found it to be responsible for a large proportion of the acute respiratory illnesses seen at a children's hospital during the winter of 1958-9. The Chicago workers also recovered two strains of virus from adult patients with acute 
respiratory disease (Hamre, Lashof, Marshall, Cassidy, Smith, and Bennett, 1961). Volunteers inoculated intranasally with monkey-kidney cultures of R.S. virus developed a cold-like illness with coryza, sneezing, and nasal obstruction. Although many of the volunteers had neutralizing antibodies to R.S. virus before infection, this did not appear to influence the subsequent development of illness (Kravetz, Knight, Chanock, Morris, Johnson, Rifkind, and Utz, 1961). It is interesting that the Philadelphia workers (McClelland, Hilleman, Hamparian, Ketler, Reilly, Cornfeld, and Stokes, 1961) found little variation in the clinical picture of R.S. infection with age within the range of a few months to 7 years. Antibodies demonstrated by the C.F. test were found in Philadelphia children in a rising percentage frequency from $16 \%$ at 1 year to $63-68 \%$ by 5 years of age. It is reasonable to assume that this virus is an important cause of illness in children, particularly because of the clinical severity of its attack and involvement of the lower respiratory tract.

\section{The Respiratory Enteroviruses (Table III)}

The role of enteroviruses in the production of respiratory symptoms was briefly mentioned in my first lecture and must again be considered. Sabin (1959) was the first to draw attention to the fact that E.C.H.O. type 10 virus, which was originally recovered from the stools of healthy children, belonged to a group of viruses larger in size than other enteroviruses ( 72 instead of the usual 25 millimicrons) and productive of distinctive cytopathic effects in monkey-kidney cultures. He christened the group, which contains three serologically different subtypes, the R.E.O. (" respiratory enteric orphans ") viruses in order to stress the affinity for both respiratory and enteric tracts. Relatively little is yet known about these agents, though they are etherresistant and multiply in newborn mice. Calves can also be infected with human Reoviruses, and natural infections have been found in these animals (Rosen and Abinanti, 1960). All three types of virus were recovered from children in Washington, some of whom were healthy whereas others had a mild febrile disease with coryza or diarrhoea (Rosen, Hovis, Mastrota, Bell, and Huebner, 1960). A strain of virus recovered by Stanley, Dorman, and Ponsford (1953) in Australia from an aborigine with respiratory disease has now been found to belong to type 3 Reovirus. The prototype type 2 virus was recovered from a child with steatorrhoea. The epidemiological relationship of these viruses to human disease is not known, but the viruses can be recovered from throat or anal swabs, and must be regarded as a possible cause of both respiratory and alimentary symptoms in children.

The recovery by Philipson and Wesslén (1958) of a virus from infants at a day nursery and children attending the ear, nose, and throat department of a hospital at Uppsala at first suggested that this was a previously unknown agent. However, it was later found (Philipson and Rosen, 1959) to be identical serologically with E.C.H.O. type 11 virus. In the Swedish children the virus, which was found both in the throat and in the faeces, was associated with a minor febrile respiratory illness sometimes accompanied by a croupy cough (Philipson, 1958). Because of its possible relation to the common cold syndrome, Buckland, Bynoe, Philipson, and Tyrrell (1959) inoculated volunteers at Salisbury with infected tissue cultures intranasally. They induced symptoms with little or no pyrexia, but the volunteers complained of abdominal pain and distension or diarrhoea. Sore throat but no coryza was observed, and the syndrome bore little relation to the transmissible common cold previously studied at Salisbury. The virus was present in faeces and in the throat, and antibody rises were demonstrated by haemagglutination or neutralization tests. Study of sera collected from a cross-section of the population and pooled by age-group showed antibodies at all ages, so that the virus is almost certainly one commonly present in England. Nevertheless it seems more likely to be associated with minor respiratory and alimentary-tract illnesses than with the common-cold syndrome.

E.C.H.O. type 20 virus was recovered from the same institution in Washington (Junior Village) as that yielding Reoviruses by Rosen, Johnson, Huebner, and Bell (1958). The virus infection was associated with fever, coryza, and copious watery or greenish stools in the affected children (Cramblett, Rosen, Parrott, Bell, Huebner, and McCullough, 1958). Some also had lowerrespiratory-tract involvement. Buckland, Bynoe, Rosen, and Tyrrell (1961) inoculated volunteers at Salisbury with material from throat swabs or tissue cultures of the virus. Symptoms resembling influenza, fever, and in some volunteers sore throat or coryza were observed in rather more than half of those inoculated. The clinical picture did not resemble that of the transmissible common cold studied at Salisbury and abdominal symptoms were less prominent than with E.C.H.O. type 11 virus. The virus was, however, recovered both from throat swabs and faeces in these adults, as in the American children. Perhaps one should add that E.C.H.O. type 20 virus was identified in cases of aseptic meningitis in Manitoba in 1959 (Wilt, Parker, Owens, and Stackiw, 1959).

Viruses classified among the Coxsackie enteroviruses have also been found to be associated with sporadic cases or outbreaks of minor respiratory illnesses. Unquestionably the most interesting virus thus far reported is that now classified as Coxsackie A 21 (Schmidt, Fox, and Lennette, 1961) and formerly termed Coe virus (Lennette, Fox, Schmidt, and Culver, 1958). Unlike the enteroviruses hitherto described as agents causing respiratory disease in children, Coe virus has been chiefly recovered from adults, and, particularly, from Servicemen with clinically undistinctive acute respiratory illnesses. In Britain, Pereira and Pereira (1959) recovered the virus from four R.A.F. patients with mild pyrexia, pharyngitis, cough, and other minor symptoms. Between 8 and $20 \%$ of admissions with respiratory illness in two R.A.F. recruit stations were associated with this virus during the winters of 1959 and 1960 (McDonald, Miller, Zuckerman, and Pereira, 1962). The virus has been found in the Netherlands in Army recruits with mild respiratory disease (Van der Veen, Oei, and Prins, 1960), and in Japan in a civilian working in a camp (Fukumi, Nishikawa, Sonoguchi, and Shimizu, 1961). By far the largest outbreak so far reported occurred in the U.S. Navy and was studied by Johnson, Bloom, Mufson, and Chanock (1962) between September and December, 1960. They noted that the virus persisted in the pharynx for many days even after the subsidence of symptoms. Volunteers inoculated intranasally at Salisbury by Parsons, Bynoe, Pereira, and Tyrrell (1960) with tissue cultures of Coe virus or throatswab material developed sore throat, coryza, malaise, and headache. Some exhibited mild pyrexia, general aching, or abdominal discomfort, but in all the illnesses 
the clinical picture included the features of typical common colds. Yet in inoculated volunteers at Bethesda given a rather small amount of virus intranasally-about 300 infectious doses-(Spickard, Johnson, Evans, and Knight, 1962) a more severe influenza-like syndrome developed in those without pre-existing antibody. It seems probable that the quantity of virus present in the inoculum given to the volunteers and their antibody status are important factors in determining the outcome.

The virus was recovered from both throat swabs and faeces collected from the infected volunteers at Salisbury, yet it failed to infect American volunteers after ingestion of enteric-coated capsules. As much as 200,000 infectious doses of virus gave no symptoms or antibody response though virus was detected in the faeces some days after ingestion by these men. So different is the behaviour of this virus from the Coxsackie A viruses associated with minor maladies of children that it is difficult to believe that Coe virus belongs to the same group. Moreover, the glimpse thus afforded of the diversity of the pathogenicity of the Coxsackie viruses should enjoin caution concerning the role of the other of these viruses about which so little is yet known.

\section{Viruses from Common Colds}

The long series of transmission experiments on volunteers at the Salisbury Common Cold Research Unit of the M.R.C. and many painfully negative attempts at cultivation culminated in 1960 in the successful studies reported by Tyrrell, Bynoe, Hitchcock, Pereira, and Andrewes (1960), by Hitchcock and Tyrrell (1960), and by Tyrrell and Parsons (1960). The chief breakthrough came with the elaboration of a technique of cultivation at $33^{\circ} \mathrm{C}$. which permitted adequate multiplication of virus and cytopathic effects in the cells of the tissue culture. Studies made in Sheffield by Hobson and Schild (1960) soon confirmed the value of the method in recovering agents from typical common colds in adults. Similar isolations have been made in Chicago by Hamre and Procknow (1961), and in New Jersey by Hamparian, Ketler, and Hilleman (1962) from adults and children with colds. The viruses thus recovered at $33^{\circ} \mathrm{C}$. cannot be demonstrated to multiply consistently or to produce cytopathic effects in the same tissue cultures cultivated at $37^{\circ} \mathrm{C}$. It has been suggested that they should be provisionally called "Rhinoviruses." Most such viruses can be cultivated originally only in human embryo tissues of which kidney has been chiefly used. A number of strains can, however, be cultivated also in monkeykidney-tissue cultures, and knowledge concerning these viruses has accumulated more rapidly than that concerning the more fastidious strains which require human embryo tissue.

Nevertheless all these "cold" viruses are not the first group to be recovered from adults with colds. The first strain of a virus now classified as E.C.H.O. type 28 (Pelon, 1961) was recovered in the U.S.A. from recruits with minor respiratory illness (Pelon, Mogabgab, Phillips, and Pierce, 1957). Price (1956) also found the same virus in nurses at the Johns Hopkins Hospital with colds and in children with minor respiratory illness in Baltimore. These viruses produced common-cold-like illnesses in volunteers both in Chicago (Jackson, Dowling, and Mogabgab, 1960) and at Salisbury (Tyrrell and Bynoe, 1958).
The E.C.H.O. 28 virus, like other enteroviruses, can be cultivated in ordinary monkey-kidney-tissue cultures incubated at $37^{\circ} \mathrm{C}$. Like the influenza and parainfluenza viruses, incubation at $33^{\circ} \mathrm{C}$. enhances its cytopathic effects, yet it clearty differs from the Salisbury cold viruses in being able to multiply at $37^{\circ} \mathrm{C}$. On the other hand, it shares other properties, such as small size and ether-resistance, with these viruses, and so the possible relationship between all these agents has to be considered. It is accepted now that the Salisbury viruses are serologically diverse, for at least six serotypes are now known, and that they are distinct from E.C.H.O. 28 (Tyrrell and Bynoe, 1961 ; Taylor-Robinson and Tyrrell, 1962) ; and there the matter must rest for the present. A move to regard the Salisbury viruses as enteroviruses has been made in the U.S.A., emphasizing the illogical situation concerning the latter. Only one unconfirmed isolation of E.C.H.O. 28 virus has been made from faeces (Price, Emerson, Ibler, Lachaine, and Terrell, 1959), and none of the Salisbury viruses have been found in this location. No one wants to render the taxonomy of viruses more difficult than it is at present, but it might surely be argued that the label "entero" implles an association with the intestinal tract such as has been demonstrated for the majority of the viruses now designated enteroviruses. Whatever the label, it seems best to accept the general similarity of E.C.H.O. 28 and the Salisbury viruses and to leave for a future international decision the best form of nomenclature.

\section{Studies of " Cold" Viruses in Sheffield}

The study of respiratory viruses in Sheffield has included work on adenoviruses, on myxoviruses, and since 1960 on viruses recovered from colds. Direct tests by Hobson and Schild (1960) on adults with natural colds yielded a number of strains of viruses which could be cultivated at $33^{\circ} \mathrm{C}$. but not at $37^{\circ} \mathrm{C}$., and studies were also made on student volunteers to obtain evidence concerning the significance of serological differences between certain strains cultivable on monkeykidney-tissue cultures. Volunteers not kept in isolation were inoculated with drops of nasal washings obtained from a volunteer at Salisbury inoculated with nasal secretion containing the H.G.P. strain. This was one of the pedigree viruses obtained originally from a natural cold in 1954 and passaged in volunteers at Salisbury between one and four times. It was found readily possible to induce colds in a proportion of volunteers and to re-isolate viruses in monkey-kidney cultures. When tests were made for neutralizing antibody in the serum it was found that susceptibility to infection was mostly confined to those with a low level or undetectable antibody in the serum (Bynoe, Hobson, Horner, Kipps, Schild, and Tyrrell, 1961). Such persons developed a sharp antibody response after infection, whereas those with previous antibody in the serum who mostly resisted infection showed no such rise in antibody levels.

Tests with a second strain of virus cultivable in monkey-kidney-tissue culture have, however, given no such relationships. The virus, originally recovered in 1960 from a schoolboy with a cold, is known as B632. Study of volunteers inoculated intranasally with nasal secretion has not shown so far that colds induced by B632 produce a rise in antibodies to this agent. Also subjects showing a rise in antibodies following infection with H.G.P. virus show no change in antibody levels to B632. Antibody-absorption tests with human sera 
confirm the serological distinctness of the two viruses H.G.P. and B632 (Schild and Hobson, 1962). An interesting finding has also emerged from antibody studies using the micro-plaque technique of TaylorRobinson and Tyrrell (1962) in tests with sera pooled by age-group and collected at random during 1953 and again in 1957. The mean levels at various ages of antibodies to H.G.P. virus recovered originally in 1954 and B632 recovered in 1957 are closely similar with both sets of sera (Schild and Hobson, 1962). A relative paucity of antibodies to both viruses is present in children, and the mean antibody titre rises steeply during adolescence to reach adult levels at about 18 to 25 years of age. Yet there are instances of high titres in individual children which suggest past infection.

\section{Comparative Serological Findings at Different Ages}

The meaning of this serological pattern to the cold viruses is not at present known, though it resembles the gradually rising curve found with antibodies to certain adenoviruses (Jordan, Badger, and Dingle, 1958) and to para-influenza type II virus (Clarke and Saynor, 1959). A pattern with more rapid rise in childhood occurs apparently with R.S. virus (McClelland, Hilleman, Hamparian, Ketler, Cornfeld, and Stokes, 1961), while infants rapidly acquire antibodies to the para-influenza type III virus.

With all these viruses it is possible to attribute the rising mean titre during childhood to selective exposure to the agent in the population, for viruses which are widely distributed, such as current influenza viruses, produce antibodies at all ages. Only with the antigens of influenza viruses no longer causative of epidemics is there a deficiency of antibodies in the children or adults born after the antigen disappeared from the population (Davenport, Hennessy, and Francis, 1953). Finally, with some agents such as the para-influenza type I group (Jensen, Minuse and Ackermann, 1955 ; Heath, Tyrrell, and Bynoe, 1962), with E.C.H.O. type 11 virus (Buckland, Bynoe, Phillipson, and Tyrrell, 1959), and with influenza C virus (Balducci, Zaimann, and Tyrrell, 1956) a relatively low and unvarying antibody titre at all ages appears to be correlated with sporadic clinical illness and perhaps widespread subclinical infection (Table IV).

It is probable that the differing antibody patterns with different respiratory viruses reflect far more than the diverse epidemiological behaviour of the agents in the population. It is reasonable to attribute the lesser

TABLE IV.-Serological Epidemiology of the Respiratory Viruses

\begin{tabular}{|c|c|}
\hline Antibodies at Different Ages & Epidemiology \\
\hline $\begin{array}{l}\text { (1) Antibodies at all ages: } \\
\text { (a) Relatively unvarying titre: } \\
\text { Influenza C (C.F.) } \\
\text { Para-influenza type I(H.I.) } \\
\text { E.C.H.O. type } 11 \text { (H.I.) } \quad \ldots\end{array}$ & $\begin{array}{l}\text { ? Sporadic endemic resp. illness } \\
\text { ? , (infants) endemic } \\
\text { Sporadic outbreaks children }\end{array}$ \\
\hline 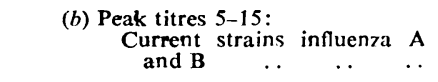 & Recurrent epidemics influenza \\
\hline $\begin{array}{l}\text { (2) Antibodies rising throughout child- } \\
\text { hond: } \\
\text { Adenovirus types 3,4,5,7 } \\
\text { (neutralizing) } \\
\text { Para-influenza type II (H.I.) } \\
\text { Respiratory syncytial (C.F.) } \\
\text { Common cold H.G.P. and } \\
\text { B632, neutralizing } \\
\text { Para-influenza type III (H.i.) } \\
\text { - rapid rise 1-2 years of age }\end{array}$ & $\begin{array}{l}\text { Outbreaks children, young adults } \\
\text { Sporadic (infants) } \\
\text { Outbreaks infants and children } \\
\text { ? Childhood incidence } \\
\text { Outbreaks and sporadic illness } \\
\text { (infants) }\end{array}$ \\
\hline $\begin{array}{l}\text { (3) Antibodies in adults not children: } \\
\text { Former influenza } \mathrm{A} \text { and } \mathrm{B} \text { virus } \\
\text { families } \ldots \\
\text {.. }\end{array}$ & Former epidemics influenza \\
\hline
\end{tabular}

incidence of disease in the adult to the possession of antibodies broadly directed against numerous groups of viruses. The antibody spectrum in children is deficient against certain agents and therefore it is likely that children will exhibit a greater degree of susceptibility to infection, or even perhaps to reinfection, than do adults. Yet other factors must be taken into account. The influenza viruses $A$ and $B$ characteristically change their serotype every few years, whereas other viruses existing in multiple serotypes already probably do not need to alter. Therefore the mere patterns of antibodies at various ages against specific virus antigens cannot readily be equated with resistance or susceptibility, and there the matter must rest.

\section{Conclusion}

This lecture began with emphasis on the overwhelming mass of respiratory infection and the greater prevalence of disease in children than in adults. It is hardly surprising that a large number of viruses have been found, therefore, once suitable techniques for their recovery were applied. It is also interesting that the majority of the reeently discovered groups of viruses have been found chiefly to be associated with illness in children. This holds for some of the adenoviruses, the para-influenza viruses, R.S., and various enteroviruses. It is still too early to comment on the role of the "cold" viruses in children because studies in this country have been made chiefly in adults. One can be reasonably sure, however, that these viruses, or strains like them, will be found in children with respiratory illnesses.

In spite of this apparent success in the laboratory those engaged in work with human specimens are only too aware of the limitations of their techniques. Negative results are far commoner than isolations of viruses, and there are probably many other viruses as yet undiscovered. Meanwhile much work is still needed to clarify the relative importance of known agents. Prophylaxis is not a practicable proposition with specific virus vaccines unless one is assured that the vaccines contain the antigens of agents causative of a reasonable proportion of observed illnesses. The sheer multiplicity of virus antigens already known appears to limit the scope of specific measures, and it is likely that the conquest of respiratory disease will depend upon the elaboration of an antiviral substance capable of a broadly directed attack.

\section{REFERENCES}

Abinanti, F. R., Byrne, R. J., Watson, R. L., Poelma, L. J., Lucas, F. R., and Huebner, R. J.'(1960). Amer. J. Hyg. 71, 52 .

Andrewes, C. H., Bang, F. B., Chanock, R. M., and Zhdanov, V. M. (1959). Virology, 8, 129.

Atkins, E. and Huang, W. C. (1958). J. exp. Med., 107, 383.

Badger, G. F., Dingle, J. H., Feller, A. E., Hodges, R. G., Jordan, S. W., jun., and Rammelkamp, C. H., jun. (1953). Amer. J. Hyg., 58, 31 .

Balducci, D., Zaiman, E., and Tyrrell, D. A. J. (1956). Brit. J. exp. Path., 37, 205.

Baron, S., and Isaacs, A. (1962). Brit. med. J., 1, 18.

Beale, A. J., McLeod, D. L., Stackiw, W., and Rhodes, A. J. (1958). Ibid., 1, 302.

Beem, M., Wright, F. H., Hamre, D., Egerer, R., and Oehme, M. (1960). New Engl. J. Med., 263, 523.

Bell, J. A., Rowe, W. P., Engler, J. J., Parrott, R. H., and Huebner, R. J. (1955)., J. Amer. med. Ass., 157, 1083.

Bennett, F. M., Law, B. B., Hamilton, W., and Macdonaid, A. (1957) tancet 2670

Bloom, H. H., Johnson, K. M., Jacobsen, R., and Chanock, R. M. (1961). Amer. J. Hyg., 74, 50.

Buckland, F. E., Bynoe, M. L., Philipson, L., and Tyrrell, D. A. J. (1959). J. Hyg. (Lond.), $57,274$. . Rosen, L., and Tyrrell, D. A. J. (1961). Brit. med. J., 1, 397 . 
Burnet, F. M. (1943) Med J Aust, 1, 385

(1960). In Virus Virulence and Pathogenicity. Ciba Foundation Study Group 4. Churchill, London.

Bynoe, M. L., Hobson, D., Horner, J., Kipps, A., Schild, G. C., and Tyrrell, D. A. J. (1961). Lancet, 1, 1194.

Chanock, R. M. (1956). J. exp. Med., 104, 555

- Bell, J. A., and Parrott, R. H. (1961). Perspect. Virol., 11, 126.

— and Finberg, L. (1957), Amer. J. Hyg., 66, 291

- and Johnson, K. M. (1961). Ann. Rev. Med., 12, 1. Kim, H. W., Vargosko, A. J., Deleva, A., Johnson, K. M., Cumming, C., and Parrott, R. H. (1961). J. Amer. med. Ass., 176, 647.

- Parrott, R. H., Cook, K., Andrews, B. E., Bell, J. A. Reichelderfer, 'T., Kapikian, A. Z., Mastrota, F. M., and Huebner, R. J. (1958). New Engl. J. Med., 258, 207 Roizman, B., and Myers, R. (1957). Amer. J. Hyg., 66, 281 .

Wong, D. C., Huebner, R. J., and Bell, J. A. (1960). Amer. J. publ. Hilth, $\mathbf{5 0}, 1858$.

Chany, C., Lépine, P., Lelong, M., Le-Tan-Vinh, Satgé, P., and Virat, J. (1958). Amer. J. Hyg., 67, 367.

Ciba Foundation Study Group No., 4, 1960 . Churchill, London. Clarke, S. K. R., and Saynor, R. (1959). Arch. ges. Virusforsch., 9, 288 .

Commission on Acute Resp. Diseases (1946). Amer. J. publ. Hlth, 36, 439.

Cook, M. K., Andrews, B. E., Fox, H. H., Turner, H. C., James, W. D., and Chanock, R. M. (1959). Amer. J. Hyg., 69, 250 Cramlett, H. G., Rosen, L., Parrott, R. H., Bell, J. A., Huebner, R. J., and McCullough, N. B. (1958)., Pediatrics, 21, 161.

Dascomb, H. E., and Hilleman, M. R. (1956). Amer. J. Med. 21, 161 .

Davenport, F M., Hennessy, A. V., and Francis, T., jun. (1953). J. exp. Med., 98, 641 .

Dick, E. C., Mogabgab, W. J., and Holmes, B. (1961). Amer. J. Hyg., 73, 263.

Duncan, I. B. R., and Hutchison, J. G. P. (1961). Lancet, 1, 530

Evans, A. S. (1960). New Engl. J. Med., 263, 233.

Flewett, T. H., and Hoult, J. G. (1958), Lancet, 2,11

Francis, T., jun., and Brightman, I. J. (1941). Proc. Soc. exp. Biol. (N.Y.), 48, 116.

Fukumi, H., Nishikawa, F., Sonoguchi, T., and Shimizu, T. (1961.) Jap. J. med. Sci. Biol., 14, 21.

Gardner, P. S., McGregor, C. B., and Dick, K. (1960). Brit. med. J., 1, 91 .

Hamparian,' V.'V., Ketler, A., and Hilleman, M. R. (1961). Proc. Soc. exp. Biol. (N.Y.), 108, 444

Hamre, D., Lashof, J. C., Marshall, J. A., Cassidy, J. E., Smith, M., and Bennett, C. R. (1961). Amer. Rev. resp. Dis., 83, 38.

- and Procknow, J. J. (1961). Brit. med. J., 2, 1382

Heath, D., Tyrrell, D. A. J., and Bynoe, M. L. (1962). To be published.

Hemmes, J. H., Winkler, K. C., and Kool, S. M. (1960). Nature (Lond.), 188, 430

Hilleman, M. R., Hodges, R. E., Warfield, M. S., and Anderson, S. A. (1957). J. clin. Invest., 36, 1072

Stallones, R. A., Gauld, R.' L., Warfield, M. S., and Anderson, S. A. (1957). Amer. J. publ. Hlth, 47, 841 .

Tousimis, A. J., and Werner, J. H. (1955). Proc. Soc. exp. Biol. (N.Y.), 89, 587

and Werner, J. H. (1954). Ibid., 85, 183

Hitchcock, G., and Tyrrell, D. A. J.' (1960). Lancet, 1, 237.

Hobson, D., and Schild, G. C. (1960). Brit. med. J., 2, 1414.

Holland, W. W., Spicer, C. C., and Wilson, J. M. G. (1961). Lancet, 2,338 .

Hope-Simpson, R. E. (1958). Proc. roy. Soc. Med., 51, 267.

Horne, R. W., Brenner, S., Waterson, A. P., and Wildy, P. (1959). J." molec. Biol., 1, 84.

Huebner, R J., Bell, J. A., and Rowe, W. P. (1957). N.Y. Acad. Sci., 5, 393 .

Isaacs, A., and Hitchcock, G. (1960). Lancet, 2, 69.

Jackson, G. G., Dowling, H. F., and Mogabgab, W. J. (1960). J. Lab. clin. Med., 55, 331.

Jawetz, E., Hanna, L., Kimura, S. J., and Thygeson, P. (1956). Arch. intern. Med., 98, 71 .

Jensen, K. E., Minuse, E., and Ackermann, W. W. (1955), J. Immunol., 75, 71 .

Chanock, R. M., Cook, M. K., and Huebner, R. J. (1960) Amer. J. Hyg., 7i, 81 .

Johnson, K. M., Bloom, H. H., Mufson, M. A., and Chanock, R. M. (1962). J. Amer. med. Ass., 179, 112 .

Jordan, W. S., jun., Badger, G. F., and Dingle, J. H. (1958). New Engl. J. Med., 258, 1041.

Kaji, M., Oseasohn, R., Jordan, W. S., jun., and Dingle, J. H. (1959). Proc. Soc. exp. Biol. (N.Y.), 100, 272.

Kapikian, A. Z., Chanock, R. M., Bell, J. A., Reichelderfer, T. E., and Huebner, R. J. (1960). Pediatrics, 26, 243. - Reichelderfer, T. E., Ward, T. G., Huebner, R. J., and Bell, J. A. (1961). J. Amer. med. Ass., 178, 537.

Kendall, E. J. C., Riddle, R. W., Tuck, H. A., Rodan, K. S. Andrews, B. E., and McDonald, J. C. (1957). Brit. med. J. 2. 131 .

Kjellén, L., Lagermalm, G., Svedmyr, A., and Thorsson, K.-G. (1955). Nature (Lond.), 175, 505

Sterner, G., and Svedmyr, A. (1957). Acta Paediat. (Uppsala), 46, 164
Kravetz, H. M., Knight, V., Chanock, R. M., Morris, J. A. Johnson, K. M., Rifkind, D., and Utz, J. P. (1961). J. Amer. med. Ass., 176, 657 .

Kuroya, M., Ishida, N., and Shiratori, T. (1953). Yokohama med. Bull., 4, 217.

Lennette, E. H., Fox, V. L.. Schmidt, N. J., and Culver, J. O (1958). Amer. J.' Hyg., 68, 272

Lindenmann, J. (1962). Virology, 16, 203

Löffler, H., Spengler, G. A., Riva, G., Stucki, P., and Mangold, R. (1956). Schweiz. med. Wschr., 86, 967

Lwoff, A., and Lwoff, M. (1959). C.R. Acad. Sci. (Paris), 248. 154.

McClelland, L., Hilleman, M. R., Hamparian, V. V., Ketler, A. Reilly, C. M., Cornfeld, D., and Stokes, J., jun. (1961). New Engl. J. Med., 264, 1169 .

McDonald, J. C., Miller, D. L., Zuckerman, A. J., and Pereira, M. S. (1962). J. Hyg. (Lond.), 60, 235.

Morgan, C., Howe, C., Rose, H. M., and Moore, D. H. (1956) J. biophys. biochem. Cytol., 2, 351.

Morris, J. A., Blount, R. E., jun., and Savage, R. E. (1956). Proc. Soc. exp. Biol. (N.Y.), 92, 544.

Nicol, C. G. M. (1957). Mith. Bull. Minist. Hlth Lab. Serv., 16 192.

Parsons, R., Bynoe, M. L., Pereira, M. S., and Tyrrell, D. A. J. (1960). Brit. med. J., 1, 1776.

Peach, A. M., and Zaiman, E. (1959). Ibid, 1, 416

Peacock, D. B., and Clarke, S. K. R. (1961). Lancet, 2, 466.

Pelon, W. (1961). Amer. J. Hyg., 73, 36.

Mogabgab, W. J., Phillips, I. A., and Pierce, W. E. (1957) Proc. Soc. exp. Biol. (N.Y.), 94, 262

Pereira, H. G., and Kelly, B. (1957). Proc. roy. Soc. Med., 50 755.

Pereira M. S., and Fisher O D. (1960). Lancet, 2, 790.

and Pereira H. G. (1959). Ibid., 2, 539.

Philipson, L. (1958). Arch. ges. Virusforsch., 8, 204.

and Rosen, L. (1959). Ibid., 9, 25.

and Wesslén, T. (1958). Ibid., 8, 77.

Price, W. H. (1956). Proc. nat. Acad. Sci. (Wash.), 42, 892

Emerson, H., Ibler, I., Lachaine, R., and Terrell, A. (1959) Amer. J. Hyg., 69, 224.

Reichelderfer, T. E., Chanock, R. M., Craighead, J. E., Huebner, R. J., Turner, H. C., James, W., and Ward, T. G. (1958) Science, 128, 779 .

Reilly, C. M., Stokes, J., jun., McClelland, L., Cornfeld, D.; New Engl.' J. Med. 264, 1176 .

Rosen, L. (1958). Virology, 5, 574

Rosen, L. (1958). Virology, 590). Amer. J. Hyg., 71, 250.

- Baron, S., and Bell, J. A. (1961). Proc. Soc. exp. Biol. (N.Y.), 107, 434

Hovis, J. F., Mastrota, F. M., Bell, J. A., and Huebner, R. J. (1960). Amer. J. Hyg., 71, 258, 266.

Johnson, J. H., Huebner, R. J., and Bell, J. A. (1958). Ibid., 67, 300

Ross, J. G., and Potter, C. W. (1961). Lancet, 1, 81.

Rowe, W. P., Huebner, R. J., Gilmore, L. K., Parrott, R. H., and Ward, T. G. (1953). Proc. Soc. exp. Biol. (N.Y.), 84, 570.

Sabin, A. B. (1959). Science, 130, 1387.

Sawicki, L. (1962). Nature (Lond.). In press.

Baron, S, and Isaacs, A. (1961). Lancet, 2, 680.

Schild, G. C., and Hobson, D. (1962). Brit. J. exp. Path. In press.

Schmidt, N. J., Fox, V. L., and Lennette, E. H. (1961). Proc. Soc. exp. Biol. (N.Y.), 107, 63

Spence, J Walton, W. S., Míller, F. J. W., and Court, S. D. M (1954). One Thousand Families in Newcastle upon Tyne. Oxford Univ. Press, London.

Spickard, Johnson, K. M., Evans, and Knight, V. (1962). To be published.

Stanley, N. F., Dorman, D. C., and Ponsford, J. (1953). Aust. J. exp. Biol. med. Sci., 31, 147 .

Stuart-Harris, C. H. (1953). Influenza and Other Virus Infections of the Respiratory Tract. Arnold, London.

Andrewes, C. H., and Smith, W. (1938). Spec. Rep. Ser. Med. Res. Coun. (Lond.), No. 228.

Sutton, R. N. P. (1962). J. Hyg. (Lond.), 60, 51

Taylor-Robinson, D., and Tyrrell, D. A. J. (1962). Lancet, 1 452 .

Tyrrell, D. A. J. (1961). Personal communication. Balducci, D., and Zaiman, T. D. (1958). and Bynoe, M. L. (1958). Ibid., 2,

- Hitchcock, G., Pereira, H. G., and Andrewes, C. H (1960). Lancet, 1, 235.

- Petersen, K. B., Sutton, R. N. P., and Pereira, M. S (1959). Brit. med. J., 2, 909.

and Cameron, A. H. (1957). J. Path. Bact., 74, 37.

and Cameron, A. H. (1957). J. Path. Bact

Valentine, R. C., and Hopper, P. K. (1957). Nature (Lond.), 180, 928.

Vargosko, A. J., Chanock, R. M., Huebner, R. J., Luckey, A. H., Kim, H. W., Cumming, C., and Parrott, R. H. (1959) New Engl. J. Med., 261, 1

Van der Veen, J., Oei, K. G., and Prins, A. (1960). Ned. T.

Wilt, J. C., Parker, W. L., Owens, A. L., and Stackiw, W. (1960)." Canad. med. Ass. J., 83, 839. 